\title{
“APRENDENDO A DIZER (SUA) PALAVRA”: UM DEBATE (AINDA) NECESSÁRIO ENTRE OPRESSÃO E FORMAÇÃO PELA MEMÓRIA EXPERIENCIAL
}

\author{
Adriana Amaral Ferreira ${ }^{\mathrm{i}}$ \\ Fabrícia Vellasquez ${ }^{\text {ii }}$
}

\begin{abstract}
Resumo: O presente artigo pretende trazer à discussão o debate ainda necessário, como sugere o título, entre os modelos de formação que se tem podido vivenciar, a partir da experiência dos sujeitos ao longo de seu próprio processo educativo. Memória e experiência, neste sentido, entram em diálogo nesse texto, a partir das contribuições de autores específicos dos estudos sobre memória (HALBWACHS, 2013; NORA, 2008; POLLAK, 1992), mas, sobretudo, interlocutando com Freire (2011), considerando-se suas inquietações presentes na Pedagogia do Oprimido. Para tanto, este trabalho traz um recorte do movimento nacional de ocupação dos estudantes universitários, em 2016, por meio de uma pesquisa biográfica do movimento discente em sua participação de constituição junto ao movimento maior, e, ao mesmo tempo, junto a um Curso que também se construía, em sua primeira turma, naquele mesmo ano. O objeto aqui analisado, portanto, se delimitou às experiências neste contexto de ocupação, tendo como limitação política e metodológica o Curso de Serviço Social da Universidade Federal Rural do Rio de Janeiro, campus Seropédica. Como resultados, o artigo apresenta alguns memoriais, especialmente construídos pela linguagem dos estudantes, entre palavras, imagens, textos verbais, fotografias que, pelas mãos e pelos movimentos organizados por eles, têm composto, até hoje, uma marca importante dessa Graduação, em especial, na Universidade, assim como em sua relação com os demais Cursos de Serviço Social de outras instituições públicas de ensino superior do estado do Rio de Janeiro.
\end{abstract}

Palavras-chave: Formação. Memória. Experiência. Educação.

\section{"LEARNING TO SAY (ITS) WORD": A (STILL) NECESSARY DEBATE BETWEEN OPPRESSION AND TRAINING BY EXPERIENTIAL MEMORY}

\begin{abstract}
The present article intends to bring to the discussion the still necessary debate, as the title suggests, between the models of formation that one has been able to experience, from the experience of the subjects throughout their own educational process. Memory and experience, in this sense, enter into dialogue in this text, based on the contributions of specific authors of memory studies (HALBWACHS, 2013, NORA, 2008, POLLAK, 1992), but above all, interlocutor with Freire (2011), considering his restlessness in the Pedagogy of the Oppressed. In order to do so, this work brings a cut of the national movement of occupation of the university students, in 2016, through a biographical research of the student movement in its participation of constitution next to the greater movement, and, at the same time, next to a Course that was also built, in his first class, that same year. The object analyzed here, therefore, was delimited to the experiences, in this context of occupation, having as political and methodological limitation the Course of Social Service of the Federal Rural University of Rio de Janeiro, Campus Seropédica. As a result, the article presents some memorials, especially constructed by the language of the students, between words, images, verbal texts, photographs, which by the hands and movements organized by them have until now been an important mark of this Graduation, in especially in the University, as well as in its relationship with the other Social Service Courses of other public institutions of higher education in the state of Rio de Janeiro.
\end{abstract}


Keywords: Training. Memory. Experience. Education.

\section{Introdução: na tentativa de aprender a palavra...}

Os oprimidos sabem, por experiência, o quanto lhes custa não aceitarem $o$ "convite" que recebem para evitar que se unam entre si

Paulo Freire

Experiência. Pela origem do vocábulo, em sua composição etimológica (CUNHA, 2010), o sentido aparece pela combinação latina do antigo verbo depoente periri /algo habilidoso/, com a preposição ex /prova, tentativa, experiência adquirida/. Na concepção histórica, portanto, 'o que se aprende habilmente por tentativas'; dentro, pois, de um processo histórico - não dado, mas vivenciado em cada momento, com reflexões de afetação. Assim é que, na epígrafe, Freire já nos "convida" - e esse sim irrecusável - a pensarmos sobre o quanto a experiência e a opressão podem ser significativas na composição das memórias formativas de seus sujeitos coletivos.

Em maio de 1968, Paris viu reacender a memória das revoluções. Para além do fato de que o evento resultou na conquista de um aumento de $35 \%$ sobre o salário mínimo, em meio à crise estrutural capitalista que vinha se configurando desde 1965, a memória mais radical de maio de 1968 está relacionada com um movimento que subverteu todo o encadeamento lógico dos começos de uma greve geral. Tudo começa pelo movimento estudantil, "o movimento começou muito inocentemente... como um movimento pela reforma da universidade. A coisa toda, ao que parece foi inflamada por uma manifestação em Nanterre (o novo campus da Universidade de Paris), resultante de medidas disciplinares contra estudantes que haviam participado de uma manifestação contra a guerra do Vietnã" iii. Não demora muito e as manifestações convergem para o Quartier Latin e, em pouco tempo, o que era uma manifestação estudantil amplia-se para o movimento operário. Cerca de quinhentas mil pessoas invadem as ruas, desde estudantes, operários fabris, músicos, dançarinos, camponeses, indicando que as diversas atividades produtivas foram interrompidas e que o movimento possui uma pluralidade e com ela o potencial emancipatório e libertário do diverso.

A atividade humana produtiva diverge ao recusar a submissão automática à lógica sistêmica do valor. A atmosfera incendiária produziu a recomposição da sensibilidade humana, a percepção sensível, de repente, desvela a atividade humana produtiva em seu ritmo criativo e passional, que não pode ser submetido ao tempo que se mede por uma cronologia abstrata, pela 
burocracia ou qualquer movimento arquitetado, a ação humana se desprende dos apriorismos e se revela livre e consciente. A base da recusa de tudo o que compõe a estrutura da sociedade capitalista nasce da percepção de que a vida pode ser organizada de modo a recusar formas tradicionais e opressivas de luta. "O movimento é, ou tornou-se espontaneamente, uma manifestação socialista e um movimento socialista, mas como disse e desejo enfatizar de novo, um movimento socialista que rejeitava desde o início a construção repressiva do socialismo". (MARCUSE, 1999). São palavras de Marcuse ao relatar para estudantes nos Estados Unidos, em 23 de maio de 1968, o que estava ocorrendo em Paris. O movimento tem início nas reivindicações estudantis pela transformação da estrutura das universidades, desde o acesso, o sistema de avaliação e a organização pedagógica repressiva, porém, subverte a própria educação no seu processo de auto-organização e luta, evidenciando seu potencial explosivo num grande movimento de resistência cultural.

Foi também em 1968 que Paulo Freire finalizava a escrita da Pedagogia do Oprimido no Chile, uma elaboração que representa a posteriori a experiência vivida, uma teoria da prática, este é o sentido de seu caráter profundamente histórico e materialista.

Quando completamos cinquenta anos do maio francês e da Pedagogia do Oprimido, rememorar aspectos do movimento francês e da obra de Paulo Freire confluem no sentido de contribuir para se pensar as ocupações das universidades pelo movimento estudantil no Brasil, em 2016. Com a particularidade de uma Universidade de origem específica, a UFRRJ, o presente artigo pretende dialogar com as provocações em "O oprimido", de Freire, e os movimentos ainda necessários, cinquenta anos depois, igualmente elaborados por seus estudantes em reivindicações que estão para além de sua formação universitária.

\section{No exercício de dizer a palavra: aspectos históricos da formação social do Brasil e a educação popular na obra de Paulo Freire}

A história do subdesenvolvimento da América Latina e de outros não se destaca do mundo pelo seu "atraso", ao contrário, é neste ponto que está integrada ao desenvolvimento capitalista mundial. Eduardo Galeano, em As veias abertas da América Latina, soube desnudar essa realidade dissimulada em destino. "Nossa derrota esteve sempre implícita na vitória alheia, nossa riqueza gerou sempre a nossa pobreza para alimentar a prosperidade dos outros: os impérios e seus nativos.” (GALEANO, 2009, P.18-19). Nesse processo unitário, o fenômeno imediato comum ao centro e à periferia foi a migração do campo para a cidade, um movimento parcialmente resultante do progresso agrícola, em que as massas fizeram declinar um modo de 
vida que não tinha mais lugar na modernidade. Foram atraídas pela universalidade atribuída à moderna economia e tudo o que isso pudesse significar de fato para a constituição de uma sociabilidade aquisitiva. Esse quase desaparecimento da população agrícola não foi uma realidade apenas dos países que acompanharam o curso "natural" da industrialização, foi também nos países em que o capitalismo moderno se formou sobre a falta desse tipo de desenvolvimento. ${ }^{\text {iv }}$ É a crítica ao fetichismo que pode explicar porque as interpretações sobre o processo de formação do capitalismo nos países "atrasados" tiveram que atribuir à ideologia um papel determinante, como no estudo de Fernandes que destaca a presença da ideologia desenvolvimentista no caso brasileiro. ${ }^{\vee}$

A ideologia desenvolvimentista também teve seu papel destacado em outro momento da história brasileira, especificamente no período que compreendeu os anos 1950 até 1964. Terminada a $2^{\text {a }}$ Guerra, a política nacional fixou-se na "superação do subdesenvolvimento", um projeto que unia as nações do "terceiro mundo" no entendimento de que a situação econômica dos países pobres poderia ser solucionada com a aceleração do processo de industrialização, que se desdobraria na consolidação da civilização moderna e da vida urbana. É neste contexto que Paulo Freire inicia seus trabalhos, estando, no período de 1959 a 1964, vinculado ao Instituto Superior de Estudos Brasileiros (ISEB). ${ }^{\text {vi }}$ Para os intelectuais isebianos, a cultura brasileira estava em crise porque não mais correspondia às circunstâncias históricas, para o que a solução seria o positivo empreendimento de se compatibilizar a cultura com o projeto desenvolvimentista nacional, sem, contudo, considerar as profundas debilidades culturais provenientes do "atraso", que não poderiam ser expelidas nem mesmo da nossa vida mental.

O trabalho intelectual voltado para "a remodelação de nossa vida mental" teve algumas experiências firmadas desde o movimento modernista, a partir dos anos 1930. Dentre elas, Arantes destaca o grupo Clima, de São Paulo (1940-1968), onde se desenvolveu um ponto de vista crítico singular que inaugurava novas mediações para a compreensão do processo de formação da cultura brasileira: "como ninguém podia saltar por cima da própria sombra, enxergava mais longe quem partia da consideração de conjunto dessas linhas evolutivas mais ou menos consistentes que estamos chamando Formação.” (ARANTES; ARANTES,1997, P.32). Nesse grupo, estava Antonio Candido que, no seu A formação literária do Brasil, de 1949, formulou uma “"apropriação original pelo raciocínio literário da ideia de formação', de um processo intelectual formativo de múltiplas dimensões, o significado do lugar central ocupado pela literatura na reconstrução mental do país.” Neste empreendimento sobre a produção literária brasileira, Antônio Candido “deu com a equação geral do problema da formação”.(idem, p. 37). Em 1969, o crítico, discutindo literatura e subdesenvolvimento, "relembra o quanto a penúria 
cultural do nosso 'atraso' não faz exceções e de fato produz uma debilidade muito mais penetrante e insidiosa do que pensam nossos letrados bem envernizados." (ARANTES; ARANTES, op.cit. p. 37-38). Neste sentido, para Arantes,

\begin{abstract}
[...] seria o caso de recordar que [...] no que concerne à índole derradeira da organização da cultura num país subdesenvolvido, Antônio Candido, dava-se ao luxo de imaginar um "socialismo pobre" que, baseado no "princípio da igualdade na pobreza, a fim de que todos possam se livrar da miséria", e levando em conta a "dimensão da natureza, as tradições culturais locais e nossas reais perspectivas científicas e tecnológicas", finalmente erradicasse o frenesi do consumo, nele incluídos todos os gadgets da indústria cultural, imposto às economias reflexas por conveniência do capitalismo central. Um projeto de reeducação? Sem dúvida, porém na órbita de uma sociedade igualitária cuja mediania realista, encarando com sobriedade a herança cultural/colonial do "atraso", permitiria enfim renovar o vínculo indescartável com a norma culta plantada pela antiga "metrópole". Uma confluência apenas imaginada, para depois de uma outra "formação". Até lá, seria o caso de ir socializando os ainda escassos recursos da cultura moderna acumulados a partir de 30 nas poucas instituições planejadas pela boa consciência ilustrada.(Idem, p. 53.Grifos meus).
\end{abstract}

Nesta perspectiva, para Arantes, o ponto de incongruência da experiência cultural brasileira está no fato de que "os percalços da articulação entre vida mental, sob constante ameaça de estar se engajando numa pista inexistente, e o panorama social próximo, cuja inconsistente razão de ser raramente favorece a dita articulação, cujo modelo de consistência sabidamente se encontra na Europa." (Idem, p. 75). Noutras palavras, numa fase de "auto-engano coletivo", buscou-se enxertar aqui um modelo de desenvolvimento sem que existissem os pressupostos sociais para tanto.

Assim, o processo de reconstrução da cultura nacional no contexto da segunda metade dos anos 1950, comandado pelos ideólogos burgueses, tinha como ponto de partida o entendimento de que se fazia imediatamente necessário aos intelectuais brasileiros, a formulação de ideias afinadas com o projeto nacional-desenvolvimentista. Estas deveriam ser transmitidas socialmente, a fim de que produzissem um impacto progressista sobre a cultura nacional, levando as massas automaticamente a questionarem, em sua consciência, sua prática social, o que deveria resultar numa sociedade civil de fato constituída e, portanto, a síntese de uma inserção social integrada e afirmativa à "moderna" realidade brasileira, fora da qual tudo é "restolho" e "desajuste". vii Seria um momento de antítese cultural, em que se teria descoberto para a sociedade brasileira um destino para o qual não havia meios? Tudo isso, na verdade, era mais mito do que fato e não deixou de ser assim, pois a tentativa de "acerto" do processo de modernização nacional para a superação impossível do subdesenvolvimento só pôde se desenhar 
enquanto ideologia própria do capitalismo periférico, o qual se processou sob um incorrigível desenvolvimento desigual e combinado.

Contudo, enquanto a experiência brasileira não tratou de desmistificar essa "falsa consciência", muitos foram os que estiveram engajados na consecução do projeto nacionaldesenvolvimentista. Este é o motivo que une Paulo Freire ao ISEB, pois, além de teoricamente afinado com suas perspectivas ideológicas, o pedagogo estava disposto a trabalhar com "objetivos inclusivos", voltado para a integração das camadas subalternas nas novas circunstâncias históricas. Entretanto, desde o início, o ponto fundamental de seu pensamento e método não é a ideologia, é a práxis. Freire tinha o foco na contradição entre a inserção prática da população na vida política nacional - um caminho aberto pela instauração da democracia parlamentar - e a ausência de uma formação política precedente que a tivesse preparado para esse exercício, não no sentido da prática formal do voto, mas numa perspectiva de que participem ativamente dos espaços públicos decisórios.

Nessa época, cujas circunstâncias políticas nacionais ganham os contornos democráticos característicos do governo Goulart, a esquerda mais radical tratava o homem subalterno primeiro como objeto, que pode se tornar sujeito por meio de ações educativas. Para Freire, o homem subalterno, tendo tido uma formação social em que foi agente legitimador da dominação das elites nacionais, precisava de uma formação em que na práxis aprendesse a agir sobre as situações determinadas de modo crítico e transformador, embora isso não se configurasse em seu pensamento como uma perspectiva socialista, pois não apoiava as formas de luta que considerava idealistas por considerar que não tinham correspondência histórica com as possibilidades da realidade nacional.

No entanto, seu método de alfabetização de adultos, desde o início, sempre pôde ser apropriado para atender a projetos políticos distintos e por vezes antagônicos: houve aqueles que tinham por base rígida os objetivos dos líderes populistas com nítidos interesses eleitoreiros e aqueles que se formavam a partir dos interesses das próprias comunidades, ainda que em aliança com as forças governamentais, como no caso das experiências culturais nordestinas, que reuniram trabalhadores do campo e da cidade em atividades de alfabetização e formação política. Nestas atividades, existiram experiências distintas, chegando a ser muitas vezes antagônicas ao proposto por Freire. Por um lado, houve aquelas em que os educadores fizeram o papel de vanguarda, o que representou um desvio negador da essência do método, por outro, existiram aquelas em que os subalternos tinham o protagonismo central no seu aprendizado político, a partir de suas experiências de vida, que ainda traziam as marcas de relações e práticas não totalmente absorvidas pela modernidade.

Revista Interinstitucional Artes de Educar. Rio de Janeiro, V. 4 N. 2 - pag 351-377 (mai - ago 2018): "Dossiê 50 anos da Pedagogia do Oprimido: movimentos de opressões e emancipações contemporâneas na América Latina e África" 
Freire se voltou para as massas subalternas, movido pela preocupação de prepará-las para o exercício da democracia representativa. Uma democracia que teria sido instituída a partir de cima, por uma estrutura legal que não correspondia à prática política real da massa subalterna brasileira, cuja formação é determinada pela "inexperiência democrática", ou seja, a democracia para os subalternos, mesmo nos termos liberais, continuava sendo estranha, pois ainda não tinham produzido objetivamente práticas políticas que pudessem interferir na esfera pública. Esse entendimento expressa a noção de processo em sua forma de interpretar a realidade, por onde consegue visualizar que a forma de participação dos subalternos certamente seria correspondente à formação política que tiveram até ali. Por isso, para Freire, ao invés de fortalecer as instituições autoritárias que continuariam conduzindo as camadas populares, era necessário encontrar meios de formação para que estas aprendessem na prática a participar da vida política.

É importante destacar que neste contexto em que somente tinham direito ao voto os alfabetizados, cerca de $50 \%$ da população brasileira ficava excluída do acesso a este instrumento fundamental da democracia liberal. Por isso, os incentivos governamentais para a alfabetização em massa com fins, sobretudo, eleitoreiros, foram determinantes para a ampliação da participação das camadas subalternas na escolha dos representantes políticos que regulariam a vida pública no país.

Tudo isso é conjugado por Freire de um modo particular, no qual podemos encontrar as indicações da compreensão que os ideólogos burgueses da época tinham do quadro cultural brasileiro. Com base em seu pensamento e, sobretudo, em seu método de alfabetização, torna-se possível identificar os impactos sociopolíticos das novas circunstâncias históricas para os diferentes segmentos sociais. Para a classe hegemônica, a aceitação do "novo" requeria uma mudança ideológica, porém, sem alterar a prática social em sua essência, ou seja, suas práticas de dominação permanecem intocadas, embora estejam agora com uma roupagem "democrática" que permite tornar os dominados formalmente mais ativos nesse processo.

Para as massas subalternas, no entanto, a inserção consciente na política não se efetivaria a partir de um salto ideológico, mas a partir de um agir novo frente às novas condições nacionais, num momento em que a realidade histórica deixava em aberto o desafio de forjar uma nova e crítica experiência na política. Este "novo agir" implicava mudanças nas formas e no conteúdo da realização das necessidades básicas destas massas, o que pode ser observado especialmente na realidade nordestina, a partir de meados dos anos 1950, onde se formaram as associações agrícolas e pecuárias dos trabalhadores camponeses, um tipo de luta alternativo à sindicalização rural barrada pelas oligarquias, criado para enfrentar de forma coletiva as Revista Interinstitucional Artes de Educar. Rio de Janeiro, V. 4 N. 2 - pag 351-377 (mai - ago 2018): "Dossiê 50 anos da Pedagogia do Oprimido: movimentos de opressões e emancipações contemporâneas na América Latina e África” DOI:10.12957/riae.2018.38032 
necessidades das comunidades rurais, a partir de uma estrutura autônoma que se mantinha fora do controle do Estado sob a denominação de "Ligas Camponesas", que seguiram ativas até 1964.

Neste contexto, também fez parte das atividades da esquerda brasileira as experiências de alfabetização e educação que percorriam principalmente as regiões mais pobres do Brasil, como a Ação Popular, constituída em 1962, reunindo a parcela da juventude católica ligada à política estudantil e ativa em movimentos de cultura e educação popular que estiveram vinculados à perspectiva pedagógica freireana. Ao analisar estes temas no período de 1964-1969, Roberto Schwarz, em Cultura e política, fala do Movimento de Cultura Popular no nordeste brasileiro e ressalta especialmente a experiência de Pernambuco. Em 1959, quando Miguel Arraes era prefeito de Pernambuco e candidato a governador, inicia-se o Movimento com a finalidade imediata de alfabetizar as massas para que pudessem acessar o direito ao voto.

Por outro lado, "havia intenção também de estimular toda sorte de organização do povo em torno dos interesses reais, de cidade, de bairro e mesmo folclóricos, a fim de contrabalançar a indigência e o marginalismo da massa", a fim de prepará-la para o "contato devastador com a demagogia eleitoral". O MCP tinha uma perspectiva reformista fundada em valores humanistas cristãos, mas na prática tinha um alcance crítico sobre "a cultura e suas formas estabelecidas". Fez parte da crítica social produzida nestas experiências, o método Paulo Freire de alfabetização de adultos, que, concebendo a leitura como "força no jogo da dominação social", procurava "acoplar o acesso do camponês à palavra escrita com a consciência de sua situação política". " $O$ trabalhador rural entrava, de um mesmo passo, no mundo das Letras e no dos sindicatos, da Constituição, da reforma agrária, em suma, dos seus interesses históricos.” (SCHWARZ, 2005, p.18-21). O método consistia em que os educadores tomassem por base palavras extraídas das experiências dos educandos - que em sua ampla maioria eram moradores das comunidades rurais - construindo, deste modo, os "temas geradores", a partir dos quais os homens aprendiam a ler, a escrever e a discutir sobre a realidade brasileira.

Neste contexto, a relação entre educador e educandos não é a mesma da educação formal em que, hierarquicamente, se dá a transferência de conhecimentos adquiridos, pois ambos protagonizam ativamente este processo de produção cultural (SCHWARZ, 2005), em que " $a$ noção de que a miséria e seu cimento, o analfabetismo, não são acidentes ou resíduo, mas parte integrada no movimento rotineiro da dominação do capital." ${ }^{\text {viii }}$ Em 1964, no Recife, "o MCP foi fechado e sua sede transformada, como era inevitável, em Secretaria de Assistência Social". (Idem, p.21).

As experiências sociais produzidas neste período e que são a própria base material da educação em Paulo Freire, o leva a deslocar o foco de seu projeto pedagógico de 1959, do Revista Interinstitucional Artes de Educar. Rio de Janeiro, V. 4 N. 2 - pag 351-377 (mai - ago 2018): "Dossiê 50 anos da Pedagogia do Oprimido: movimentos de opressões e emancipações contemporâneas na América Latina e África" 
objetivo de formular um modo de educação funcional ao desenvolvimentismo para o compromisso com o aprofundamento das experiências de autoformação das massas. É uma mudança que não emerge do aprofundamento da teoria, mas de suas práticas pedagógicas. Em Educação como prática de liberdade, livro publicado no Brasil em 1967, está explícita essa "virada" da perspectiva freireana, de um projeto pedagógico funcional ao nacionaldesenvolvimentismo para um objetivo político contrário às elites, mobilizando a massa subalterna, embora isto apareça nesse momento mais como objetivo prático do que como sistematização teórica, pois a compreensão teórica do alcance de seu método pedagógico é posterior às suas primeiras experiências.

As primeiras elaborações teóricas que definem a perspectiva crítica e libertária da pedagogia desenvolvida por Freire foram construídas durante o período em que esteve exilado no Chile, entre 1964 e 1969, quando, além de continuar envolvido em experiências de educação popular, produziu a análise das práticas educativas realizadas no Brasil entre 1959 e 1964, resultando no livro Pedagogia do oprimido, escrito entre 1967 e 1968, publicado no Brasil em 1974. É a obra que nos leva a compreender que na base do pensamento de Paulo Freire existe uma "filosofia da práxis". É no conceito marxiano de práxis que Freire entende o processo de formação do ser e da consciência.

O único caminho a seguir [...] é a conscientização da situação [...] conscientização, é óbvio que não para, estoicamente, no reconhecimento puro, de caráter subjetivo, da situação, mas, pelo contrário, que prepara os homens, no plano da ação, para a luta contra os obstáculos à humanização." "É preciso que fique claro que [...] estamos defendendo a práxis, a teoria do fazer, não estamos propondo nenhuma dicotomia de que resultasse que este fazer se dividisse em uma etapa de reflexão e outra, distante, de ação. Ação e reflexão se dão simultaneamente. (Cf. FREIRE, P. Op cit. p. 158; 172-3).

Não obstante, foi possível a Freire elaborar uma pedagogia de formação política produzida a partir da experiência social porque a realidade brasileira - principalmente o nordeste, onde esteve diretamente envolvido em práticas de educação popular no período - ainda não havia totalmente consolidado as relações e práticas sociais que passariam a fazer parte do conjunto da vida social moderna. Por isso, considerando as bases históricas em que desenvolve seu pensamento, foi possível falar de práxis sem mediações muito aprofundadas sobre a crítica do fetichismo.

Por outro lado, esse contexto que tornou possível a elaboração do pensamento de Freire indicava que no território nacional inexistiam bases materiais capazes de impulsionar um movimento espontâneo de modernização da vida social, de modo que o Golpe de abril de 1964 e os vinte e um anos de ditadura civil-militar que se seguiram - com a participação do governo 
norte-americano interessado em expandir o domínio imperialista sobre a América Latina e em mitigar as influências comunistas produzidas num contexto marcado pela Guerra Fria e pela Revolução Cubana - tiveram o papel de fabricar as mediações necessárias para que a materialidade da vida social fosse totalmente produzida sob a forma abstrata. Este processo produziu nos indivíduos a assimilação de um tipo abstrato de prática social em que eles mesmos se autodisciplinam para a realização das funções postas pela sociedade burguesa, de modo que o processo autocrático repressivo, depois de duas décadas, tornou-se dispensável. ${ }^{\text {ix }}$ Daí por diante, nem de "violência ideológica se poderá falar"(ARANTES, 2007), já que quase todos estiveram de acordo com o aprofundamento da lógica de utilização abstrata do homem e da natureza, inclusive a classe proletária que, integrada socialmente, teve sugada pelo capital as forças políticas de contraposição que fizeram parte do processo que impulsionou a expansão capitalista no território nacional.

A modernização da sociedade brasileira dissolveu o tipo de prática política que esteve na base das experiências sobre as quais Paulo Freire construiu sua concepção popular de educação. As lutas sociais da massa subalterna existentes no pré-64 tinham o caráter popular de serem originadas espontaneamente no território social comum - lugar de moradia que, na zona rural, era o próprio lugar de trabalho -, onde as pessoas viviam relações definidas por uma vinculação social produzida nas tradições das experiências comuns, no convívio e no modo com que lidavam com a natureza ${ }^{\mathrm{x}}$. Este foi o terreno em que se produziram experiências políticas autoorganizadas, a partir das necessidades sentidas e elaboradas coletivamente na comunidade, enquanto espaço efetivo de luta e formação política.

Mas, os anos do regime ditatorial, que se estenderam até 1985, produziram a violenta dissolução do modo de vida propício à produção deste tipo de organização, instituindo formas legais de luta e incorporando a participação da população ao interior das modernas instituições sociais. O processo de modernização das lutas populares produziu a sua desradicalização, dissolvendo a forma de organização que tinha base territorial para integrá-las às instâncias de controle institucional.

Desse modo, o aprofundamento das condições de existência da sociedade moderna pôde ser sentido na experiência social que, repleta de fantasmagorias, não mais vinculava os homens à sua riqueza cultural. A impossibilidade de que as forças invisíveis que governam a vida prática se autoevidenciem tornou cada vez mais difícil que a formação política de caráter emancipatório pudesse nascer espontânea da experiência social real. Na sociedade capitalista em expansão, capaz de assegurar as mínimas condições de reprodução social para os que trabalham e de 
integrar por vias assistenciais a parcela improdutiva da população, a atividade humana real não mais atestava a atualidade histórica da "pedagogia do oprimido".

O chão histórico constituído pelo tipo de experiência que foi a base matrial da concepção freireana de educação havia sido destruído e no seu lugar a abstração real abriu um grande fosso. O fato é que as lutas com perspectivas efetivas de transformação social não subsistiram ao ocaso de $1964^{\text {xi }}$. De lá pra cá, andamos e pensamos em círculo. O fetichismo diluiu as lições que a história nos ensinou e continuamos andando em círculos, retornando sempre aos mesmos lugares, mas sob condições que não permanecem as mesmas e se tornam cada vez piores.

A derrota política da esquerda depois do golpe civil-militar de 1964 significou a interrupção do processo que deu visibilidade ao potencial transformador das lutas da classe trabalhadora brasileira, o que foi retomado aos poucos no fim dos anos 1970 e início dos anos 1980, com a fundação do PT (Partido dos Trabalhadores) ${ }^{\text {xii }}$ que buscou se distinguir criticamente do PCB, significando "uma ampla e nova possibilidade de construção de um partido revolucionário no Brasil", mas que durou até a derrota nas eleições presidenciais de 1989, quando o PT "entrou num processo defensivo de resistência em que a sua base social foi desconstruída" (MENEGAT, 2008, p.13). A nova derrota da esquerda brasileira evidenciou que as possibilidades reais de transformação estrutural do país pela via das políticas desenvolvidas no âmbito do Estado foram diluídas com o fim do período de expansão econômica do capitalismo mundial e a crise estrutural do capital, o que altera fundamentalmente o caráter do PT e das lutas da classe trabalhadora brasileira de modo geral, cuja radicalidade, em outro momento da história, adveio da possibilidade objetiva de realização de reformas sociais que, durante o processo de expansão econômica, podiam encontrar viabilidade para serem ampliadas até a alteração profunda da estrutura social de classes.

$\mathrm{Na}$ realidade, a classe trabalhadora constituída na periferia do capitalismo sempre sofreu os drásticos efeitos do desenvolvimento social tardio. No Brasil, isto se expressa de forma emblemática no conjunto de direitos de cidadania reunidos na Constituição Federal de 1988 que ampliou as funções do Estado no campo das políticas de seguridade social, além de prever a abertura das instituições para a participação regulada da população em instâncias de controle do uso dos recursos públicos - que chegaram para a classe trabalhadora brasileira tardiamente, quando a crise estrutural do capital já estava instalada nos países de economia central e a viabilidade histórica do Estado de bem-estar social já havia se diluído com o fím do período expansivo do modo de produção capitalista.

As regras da economia global, sobretudo a partir de 1989 - explicitamente adotadas nos governos Collor, Itamar e FHC - passaram a orientar o corte do financiamento das funções Revista Interinstitucional Artes de Educar. Rio de Janeiro, V. 4 N. 2 - pag 351-377 (mai - ago 2018): "Dossiê 50 anos da Pedagogia do Oprimido: movimentos de opressões e emancipações contemporâneas na América Latina e África" 
sociais do Estado, de modo que as (contra) reformas sociais atingiram em primeiro plano a massa dos desempregados, pois também não poderiam buscar a produção de condições de sobrevivência social pela via pública estatal. A reversão desta condição do Estado - por ser uma situação dada pela crise estrutural, não podendo ser alterada por nenhum tipo de saída política não é mais possível, o que não requer apenas uma crítica às prioridades que definem o gasto do dinheiro público, mas uma crítica ao próprio Estado enquanto parte constitutiva de uma unidade com o mercado ${ }^{\text {xiii }}$.

Por outro lado, para os "novos" movimentos sociais formados na América Latina, neste contexto, a produção de práticas coletivas em torno do objetivo imediato de superação da fome e da miséria tem o significado da reconstrução do cotidiano, a partir de novas formas de vida comunitária. É neste sentido que, na Argentina, o movimento dos piqueteiros (MARRO, 2009) transformou a política de assistência social do governo, voltada para o controle das massas pauperizadas, no princípio da construção de formas autônomas de vida social, ao utilizarem "as migalhas monetárias arrancadas do Estado para fomentar a auto-organização política econômica no cotidiano da população nos bairros pobres da periferia". (FERNANDES, 2011). A ressignificação dada pelos piqueteiros ao dinheiro que recebem do programa assistencial do Estado tem seu ponto de sustentação econômica na construção de um fundo comum, autogerido para financiar, sobretudo, as necessidades coletivas básicas de alimentação, pois com o aprofundamento da crise do capital nos anos 1990, a pauperização em níveis surpreendentes tornou a fome o principal legado do horror econômico para a massa subalterna.

No Brasil, o MST tem representado uma forma de luta que reúne o novo e o velho. É exatamente o que ele traz de novo que o tem feito o movimento que melhor tem subsistido à repressão, à criminalização e à assistência social. A reforma agrária, depois de 1964, diluiu-se em ações que ocuparam um lugar marginal nas políticas de governo, dado que a crise estrutural tornou inviável o aprofundamento das políticas de redistribuição da riqueza social, prevalecendo em seu lugar as medidas agressivas de modernização do campo que beneficiaram a ampliação do agronegócio, aprofundando a subordinação econômica do país ao capital internacional.

Isto está diretamente relacionado ao fato de que a repressão aos movimentos do campo não cessou com o fim da ditadura civil-militar, de modo que as prisões, torturas e mortes, enquanto forma de controle social do Estado sobre a massa humana não mais rentável, são vivenciadas, sobretudo, pelas cerca de 150 mil famílias de trabalhadores rurais sem terra acampadas em diversos pontos do território nacional. Talvez o tipo de organização política do MST, que tem sua base na luta territorial, possa explicar porque tantas famílias sem terra resistem à repressão. A luta pela terra os mantém unidos não só pela ocupação e conquista do espaço físico de 
moradia e de produção do alimento, mas igualmente pelas práticas coletivas em torno da agricultura camponesa, que vão reconstruindo a relação do homem com a natureza e os laços humanos de solidariedade destruídos pela forma social de vida moderna, o que produz entre eles um tipo próprio de vinculação cultural orgânica com o movimento.

Estes são indicativos de que o reverso da crise contém elementos de uma alternativa histórica à barbárie social que podem ser observados na práxis de segmentos das massas, cuja situação aguda de carecimento material, dada a inexistência de saídas para suprir necessidades imediatas no plano das políticas sociais, tampouco no plano do emprego, tem impulsionado a produção de experiências coletivas de resistência às formas abstratas de dominação na história. Os aspectos comuns destas experiências observadas entre os novos movimentos sociais da América Latina confluem numa forma de organização que, distinta das formas de luta típicas da modernidade, tem em sua base o sentido da "pedagogia do oprimido", cujo significado histórico se reatualiza. Pois, somente a atividade organizativa com potencial de transcender os circuitos de automovimento da mercadoria, voltada para a crítica da abstração real e a emancipação humana da sociabilidade fetichista, pode realizar integralmente a pedagogia freireana. Os oprimidos somente poderão tomar a história nas mãos se produzirem um tipo de experiência social resistente ao automatismo da lógica do capital, a partir do processo em que deixam para trás toda forma de assujeitamento e livremente decidem colocar mulheres e homens conscientes e afetivos no lugar das coisas ${ }^{\mathrm{xiv}}$.

Neste mesmo sentido, no Brasil, em 2016, as ocupações estudantis contra os processos de regressão da educação pública tiveram início nos movimentos secundaristas, as ocupações das escolas públicas - totalmente imprevistas pelo ponto de vista lógico da luta de classes produzindo o embrião de uma nova tradição no movimento estudantil. Mais além da sua bandeira em defesa da educação, subverteram a própria educação. De modo que não se podia falar que foi interrompido o processo de formação no período da ocupação, muito pelo contrário, a formação humana, política e cultural aprofundou-se em termos de crítica, criatividade a autonomia.

Foi na base que se produziram os começos do movimento em diversas regiões brasileiras. E se ampliou para as universidades, de modo que os trabalhadores da educação, professores e técnicos são levados a aprender com os estudantes e suas formas de auto-organização. Por alguns meses, foram eles que decidiram se cumpririam as atividades inicialmente definidas nos programas de ensino ou se permaneceriam na ocupação - tomando decisões, participando dos debates públicos que eles mesmos organizavam, produzindo experiências culturais - não seria 
mais "produtivo". A formação estava organizada em torno do tempo livre e não do calendário acadêmico.

Foi do movimento estudantil que emergiu a greve de professores e técnicos que durou cerca de seis meses em algumas universidades. O movimento que reivindica mudanças estruturais na educação, subverte-a desde o começo, pois é no próprio movimento que se produz uma pedagogia de autoformação que é, também, profanação das formas tradicionais de se fazer política e pode ser lida nos termos da pedagogia freireana. Partimos, assim, de uma experiência em memória de um Curso de Graduação em Serviço Social, recentemente criado, e localizado na Universidade Federal Rural do Rio de Janeiro (UFRRJ), campus Seropédica. Diante dos vários movimentos de ocupação nos cursos superiores, gerados a partir do movimento secundarista de 2016, a escolha dos registros desse Curso, em particular, se dá, especialmente, por se tratar de uma graduação, cujo início ocorre quase que concomitantemente à conjuntura maior de mobilização nacional dos estudantes, quanto por ser uma formação, cuja matriz curricular orientada pelas Diretrizes Curriculares do Serviço Social ${ }^{\mathrm{xv}}$ junto ao MEC - enseja uma formação crítica, propositiva e criativa.

\section{Da aprendizagem de suas palavras: a memória experiencial pelos movimentos $d e$ e em}

\section{formação}

A palavra - e a capacidade de tomá-la para si - sempre fora uma preocupação de Freire. Aprender, portanto, a dizer a própria palavra, como sugere o título deste artigo a partir das próprias contribuições do autor, ainda requer, de todos nós educadores, a compreensão de que cada movimento dessa conquista requer participação e apreensão do processo histórico com que se constituem as relações sociais. Da tomada essencial da palavra, assim, está também nossa capacidade - ou oportunidade, ousadia, resistência - de não aceitar a história contada simplesmente por outrem. Se a palavra, assim, é elemento de entrelace da memória, a história também é combustível para a busca do entendimento dos sentidos possíveis à palavra. E do conjunto dos significados, o passo necessário à chegada do conceito por si, pelo grupo, em sua experiência própria.

Ainda na perspectiva etimológica, em sendo a proposição textual aqui elaborada o festejar de meio século da obra de Freire, a comemoração é também por nós tomada como o ato de estar junto à memória, revisitando-a. Nesse sentido, entendemos como fundamental conhecer o processo histórico com que se deu o objeto aqui trazido à discussão para o diálogo com a obra de Freire. O Curso de Serviço Social da UFRRJ teve início no segundo semestre de 2015, no campus Seropédica, com seu projeto de criação desde 2011, por uma equipe composta por 
professores e por servidores com formação em Serviço Social, em Economia Doméstica, além da colaboração de entidades representativas da área como a Associação Brasileira de Ensino e Pesquisa em Serviço Social (ABEPSS) e o Conselho Regional de Serviço Social (CRESS/7 ${ }^{\circ}$ Região - RJ). Elaborado, pois, a partir de muitos sujeitos, com particularidades de formação diversas, se constituiu, também, a partir da relação entre as memórias individuais e coletivas de cada indivíduo, bem como de cada grupo em especial, tal como nos sugere Halbwachs (2013).

Neste artigo, procuramos recortar a questão que envolve a memória do Curso, dando foco na participação discente nessa elaboração, em plena ocupação estudantil nacional que se construiu, e se constrói, desde a chegada da primeira turma, se renovando, como construção, a cada novo ingresso de turma. Partindo, assim, da experiência formativa de Freire (2011) e dos lugares de memória de Nora (2008), temos aqui tomado o Curso em questão como uma possível atualização da capacidade auto-organizativa dos estudantes que geram pautas, demandas, reivindicações e recolocam a organização instituída da Universidade a partir de seus movimentos instituintes.

Ainda no tocante à história, e para entendermos a formação desta memória, precisamos também compreender, a priori, a localização da Universidade e de seu público, ou perfil, que o Curso de Serviço Social costuma atender como corpo discente. A Universidade possui seu campus principal, Seropédica - onde o curso tem se realizado em suas primeiras turmas -, localizado em uma região bastante peculiar na geografia do Estado do Rio de Janeiro: a aproximadamente $80 \mathrm{~km}$ da Capital do Estado, ocupa terras que formaram, no passado colonial, a antiga Fazenda Jesuítica. Atualmente, é a principal possibilidade de oferta de ensino superior público para regiões como a Baixada Fluminense, Zona Oeste do Município do Rio de Janeiro, Vale do Paraíba, Costa Verde, Sul Fluminense e parte significativa da Região Serrana.

Ao perceber que os estudantes, do curso e universidade em questão, vieram de lugares diferentes, apesar de muitas localidades com características semelhantes ou próximas (especialmente quanto à falta de recursos, a dificuldade de acesso aos direitos sociais básicos), compreendemos como os mesmos chegaram à Universidade com percepções e com memórias diferentes. Traziam, pois, desde 2015, com a primeira turma, histórias de vida que, mesmo em se aproximando umas das outras, resguardavam, também, muito da subjetividade de cada um, a partir do ritmo e da possibilidade de resistir às constantes dificuldades impostas.

Contextualizar a trajetória do curso de Serviço Social da UFRRJ requer que façamos uma articulação entre sua memória e sua identidade em sua forma discente (que está em construção), de maneira que possamos lembrar - ou selecionar lembranças - de quem são, ou somos, em suas dimensões individuais, mas especialmente coletivas - quando da representação de grupos, de 
turmas, de Curso, não apenas no espaço formativo, mas diante da Universidade. O movimento de diálogo entre o individual e o coletivo, portanto, será também evidenciado no presente artigo, como necessidade de buscar, nessa interseção, as tessituras que forjam um Curso em formação, a partir de seus sujeitos também - e em eterno - desenvolvimento.

Tal como a história é essencial para qualquer compreensão e análise crítica que façamos do objeto, igualmente o é o entendimento do conceito de memória, pela experiência, a que nos referimos desde o título provocativo à reflexão. A memória, em sua totalidade, pode conter vários sentidos, a depender da sujeição em que ela se encontra ou até mesmo da forma como ela é tratada. Podemos apontar, dentro do debate de memória, o processo individual e o conceito como processo de construção social, ou seja, memória individual e memória coletiva. Até o final do século XIX e início do século XX, se pensava apenas em memória individual; o "novo" conceito, a partir daí, traz, junto à ideia de memória coletiva também a própria memória social. Para Freire (2011), a memória deve nos servir de elemento se junto à experiência, considerandose as possibilidades de intervenção dos sujeitos em seus próprios cotidianos.

A respeito da memória individual, segundo Pollak (1992), quando se trata dessa perspectiva de construção, seus modos podem ser tantos cientes como inconscientes. Em seu trabalho Memória e Identidade Social, o autor apresenta que a memória parece ser um fenômeno individual, algo relativamente íntimo, próprio da pessoa. Porém, Maurice Halbwachs (2013), por volta dos anos 1930, já havia sublinhado que a memória deve ser entendida também, ou principalmente, como um fenômeno construído coletivamente e submetido a flutuações, transformações e mudanças constantes. E isso pressupõe, inclusive, que é parte da memória a lembrança e o esquecimento, a retomada do fato vivido ou mesmo o imaginado. Na experiência de Freire, pois, a autonomia dos sujeitos seria também o elemento fundamental para que os sujeitos coletivos criem - e analisem - seus memoriais formativos.

$\mathrm{O}$ ponto em comum, quase como um conceito-chave, que tem atravessado os autores sobre memória é a relação entre memória e história - a partir do elemento dialético lembrançaesquecimento. Pollak (1992), no entanto, consegue extrapolar o efeito binário provocativo, ampliando o debate para além do individual e coletivo, inclusive. Acrescenta, como proposição, a possibilidade de se pensar a memória como algo maior: sua apropriação, pelos sujeitos, como marca de uma identidade não apenas do grupo, mas social, de (re)conhecimento de outrem. Nesse sentido, e em diálogo com Freire, o autor propõe, sobretudo, a recuperação dos "vestígios de memória", também ao dialogar com Pierre Nora, e destaca, nas histórias de vida - agora também consideradas como história oral, segundo ele - as marcas inscritas, mas passíveis de apagamento, inclusive pelos próprios sujeitos que as inscrevem. Procura, com isso, entender 
como se constitui a memória: pelos persona(gens) - pessoas reais ou não - e lugares. E mesmo quando destaca os locais que suportam a memória, não deixa, com isso, de evidenciar os sujeitos na relação com esses lugares. Os sujeitos são, para ele, os verdadeiros guardiães da memória. Assim:

Além dos acontecimentos e das personagens, podemos finalmente arrolar os lugares. Existem lugares da memória, lugares particularmente ligados a uma lembrança, que pode ser uma lembrança pessoal, mas também pode não ter apoio no tempo cronológico [...]. Na memória mais pública, nos aspectos mais públicos da pessoa, pode haver lugares de apoio da memória, que são os lugares de comemoração (POLLAK, 1992, p. 202).

Institui, em seus estudos, uma marca significativa de ratificar a ideia de memorial como algo que não apenas pode ser não-fixo, atemporal, como, especialmente, se evidencia pela interlocução entre os sujeitos e pela movimentação que cada indivíduo faz com a própria memória quando se desloca. Em sendo os sujeitos suportes-guarda do memorial, eles levam, consigo, tudo o que eles mesmos produzem e querem expor dessa produção de si e do coletivo. O memorial, em diálogo com Freire, poderia ser por nós compreendido como o lugar da experiência que pode gerar a (auto)fomação.

Pela transitoriedade e pela movimentação inerentes à memória, Pollak justamente critica os efeitos datados do memorial. Questiona, com isso, os símbolos fixos, cuja materialização acaba por aproximar tempo e espaço como um único conceito de tempo-espaço: os monumentos, as estátuas, os mausoléus. Da memória com a qual dialogamos, pois, no presente trabalho também requer que consideremos, sobretudo, a incapacidade de registrarmos tudo e todos, e para sempre. Queremos, sim, atribuir à memória do Curso a capacidade de continuar existindo por ela mesma, especialmente considerando sua incompletude e sua inquietação constantes também em função da relação entre as muitas reminiscências de sujeitos diferentes, sendo "analisados" e analisando o mesmo processo.

Dessa dialética entre eu e nós, o destaque retoma a categoria tempo a partir de outro movimento similar que é a aproximação entre o presente e o passado das lembranças. Assim, Halbwachs nos provoca sobre a memória viva, presente, e que se constitui na materialidade do que se está mais passível de lembrar; e, em outro sentido, pelo passado, a partir de uma memória que, apesar de material, só é lembrada pela (re)construção dos dados, dos fatos, das pessoas. E tanto pelo momento do/no ato, quanto pelos fatos nos trazido por alguém, a memória, ele afirma, sempre será coletiva, porque experiencial. Dentro da organização da memória do Curso, temos podido compreender que ao se mencionar sobre eventos e acontecimentos passados, desde a criação do curso, cada pessoa com sua participação traz sua impressão, e todas essas impressões 
juntas recomeçavam a reconstrução da experiência de uma memória vivida, no caso, a memória coletiva do curso.

Entendemos, porém, que para que uma lembrança seja reconhecida e reconstruída, se faz necessário que ela se realize a partir de dados ou de fatos comuns, uma vez que não é suficiente ou possível reconstruir peça por peça, e imagem por imagem de um acontecimento, especialmente considerando os diversos momentos - e movimentos, e sujeitos - por que já passou o Curso, apesar de apenas três anos de existência desde seu início. Era preciso, assim, considerar um recorte metodológico coerente e, ao mesmo tempo, abrangente, apesar da necessidade do corte temático ou de pesquisa. Assim, para a elaboração dessa memória social, partimos da reconstrução da memória através do grupo discente participante, como forma de protagonismo a esse grupo que, apesar de fundamental à Universidade, ainda se apresenta, neste espaço, com pouca voz ou em relação desigual de poder, no tocante à tomada de decisões junto à instituição formativa. A metodologia utilizada foi a pesquisa e a formação de um portfólio, como suporte memorial, utilizando, como fonte, as redes sociais dos próprios estudantes e as plataformas de divulgação de eventos e de acontecimentos relativos ao Curso também por sujeitos e canais institucionalizados (páginas e plataformas da Universidade, por exemplo).

No viés dessa perspectiva deve-se tomar o cuidado com imagens produzidas a partir de relatos, já que elas podem se confundir com as lembranças. Segundo Halbwachs (2013), de um lado os depoimentos de outras pessoas dão suporte à reconstrução da lembrança apagada; de outro, nós nos lembramos, em aparência, sem o apoio dos demais, de impressões que não comunicamos a ninguém, resultando em memória individual. A memória social manifesta-se nas memórias individuais, fazendo, dessa forma, com que aqueles que apreendem lembranças tragam sempre à tona memórias construídas de forma coletiva.

Especificamente quanto à memória do curso de Serviço Social, temos que, desde seu surgimento, o Curso vem conseguindo seu lugar de memória, sem, com isso, estabelecer ancoragens. Em um espaço, como a UFRRJ, com todos os resquícios particulares de uma universidade centenária, e com suas raízes na ESAMV - Escola Nacional de Agricultura e Medicina Veterinária, a preservação desta memória, sem permitir grandes lacunas, tem sido também entendida como uma resistência de permanência do próprio Curso. Desde as primeiras ações, portanto, o cuidado com as histórias da Graduação conta com um movimento que é de construção, de um forjar de memória que perpassa pela identidade. Por uma (nova) ou outra identidade a esse lugar de experiência, de memória, de formação.

Aportamos nesse primeiro ponto: a construção da identidade visual do Curso, a partir das características da Universidade e de seus símbolos - tanto do Serviço Social, como profíssão, 
quanto de uma instituição de bases rurais. Essa identidade, que também guarda, como lugar, uma memória, fora constituída inicialmente com ideias dos primeiros alunos, ainda em 2015. Era, assim, um primeiro movimento de participação discente, que procurava, na Universidade, emitir uma mensagem que compusesse sua memória, afinal, "a escolha do canal visual, pictórico ou gráfico, depende não só da matéria a codificar, mas também dos indivíduos a quem se dirige" (FREIRE, 2011, p. 66). Na perspectiva freireana, assim, as roldanas - ou rodas - de equipamentos do mundo rural passam a integrar, propositalmente, a balança da justiça social do contexto profissional, tal como nos ilustra a seguir:

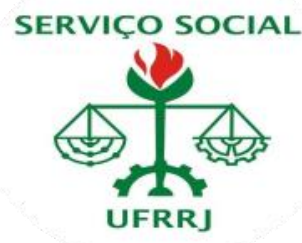

Figura 1 - Símbolo do Curso de Serviço Social da UFRRJ

Os alunos de Serviço Social da UFRRJ têm construído, dessa forma, uma identidade formativa própria, marcada pela historicidade de luta da profissão e pela atuação do Movimento Estudantil da Universidade Rural. O segundo movimento, neste sentido, foi a criação do Centro Acadêmico Dandara dos Palmares (CA). Ainda no primeiro semestre letivo, em 2015.02, o CA não apenas estava institucionalizado como contava, no mesmo contexto, com uma identidade visual própria, à semelhança da imagem do Curso, e que contemplava, vale dizer, a própria identidade imagético-textual da Graduação com a qual também se relacionavam na Universidade.

Por ser um Curso essencialmente do gênero feminino, como é da história da profissão, a escolha pela representação do CA na figura de Dandara - e cujo rosto se estampa no CA - é, por aquele grupo, entendido como mais do que simbólico; é, sim, uma marca de resistência. À própria universidade, inclusive, especialmente considerando o histórico conservador de uma instituição pública, cujos primeiros cursos, vale destacar, sequer consideravam mulheres. A imagem do CA, pois, é uma tomada de demarcação de um espaço que marca o Curso, mas que o extrapola, gerando o debate. Assim:

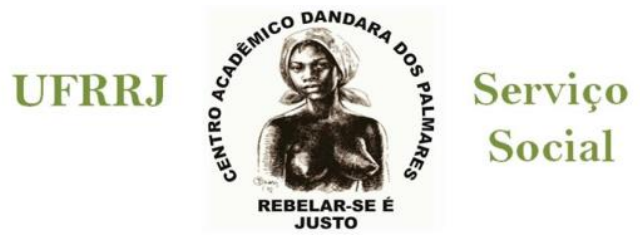


Figura 2 - Símbolo do Centro Acadêmico de Serviço Social da UFRRJ - Dandara dos Palmares

O Centro Acadêmico de Serviço Social Dandara dos Palmares, o CASS UFRRJ, foi fundado em onze de dezembro de dois mil e quinze, no final do primeiro período letivo da primeira turma, durante uma Assembleia Estudantil. Em 2016, os alunos, e principalmente as alunas, também se unem ao movimento de mulheres da UFRRJ, cuja bandeira era a resposta da administração superior quanto aos constantes casos de violência de gênero, em que muitos estupros e outras naturezas de agressão à mulher eram cometidos há anos dentro do campus. A partir do movimento "me avisa quando chegar", as estudantes do Serviço Social também tiveram importante participação e se organizaram no que pode ser considerado um dos maiores, inclusive em termos quantitativos, atos contra a violência à mulher: a ocupação da reitoria e a paralisação das atividades da Universidade e das vias do entorno, como a Rodovia Presidente Dutra. O gênero feminino, historicamente presente na formação, assume, já em 2016, um novo lugar no Curso da UFRRJ:
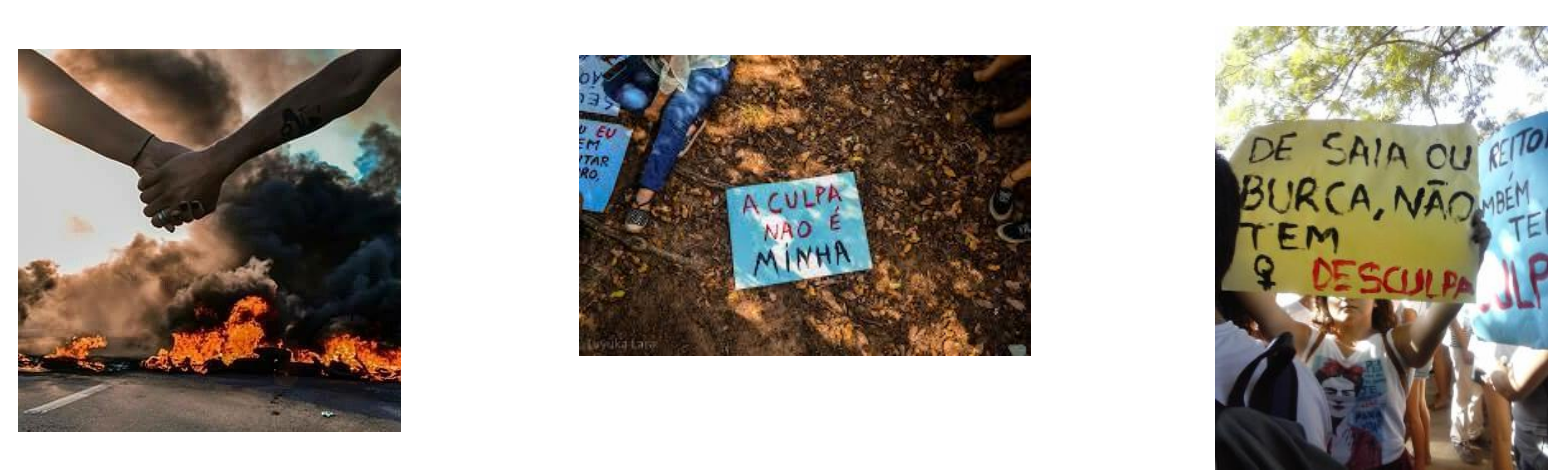

Figuras 3, 4 e 5 - Participação das alunas junto ao Movimento "me avisa quando chegar"

Aproximadamente um ano após a criação do CASS se consolidava o movimento estudantil de ocupação, já com os discentes articulados internamente, com constantes assembleias via CASS. Neste contexto, a UFRRJ foi a primeira universidade do Rio de Janeiro a ser ocupada, tendo, em seguida, várias outras a segui-la. E, na composição do memorial do Curso, muitas foram as participações dos discentes, como grupos e através do CASS, desde atividades representativas na Universidade, em cuja relação os alunos se dividiam em comissões organizativas na UFRRJ, até a integração nacional pelo movimento de ocupação. 


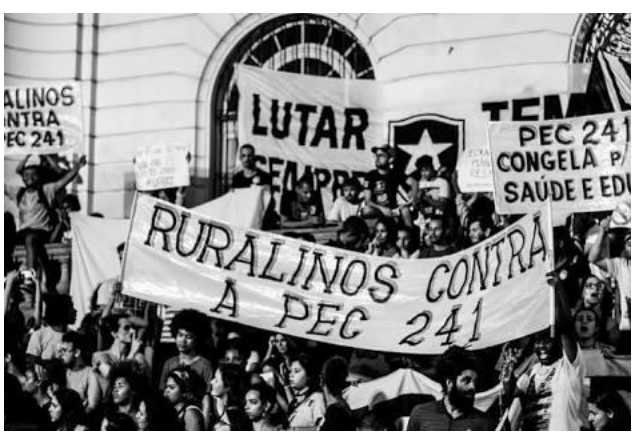

SOU DE SERVIÇO SOCIAL

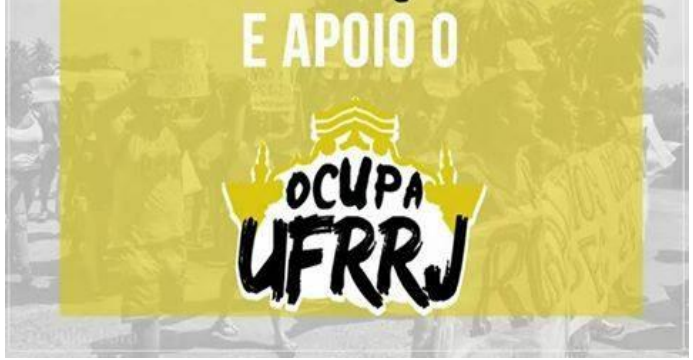

Figuras 6 e 7 - Imagens do acervo de fotos do curso de Serviço Social sobre a ocupação

Esse movimento social teve sua influência no processo de construção de representações, de visões de mundo e de modos de vida dos estudantes universitários que nele se inseriram, bem como as contribuições dessa participação política em suas trajetórias. Em atuação resistente, os estudantes da UFRRJ permaneceram cinquenta e quatro dias ocupados, de outubro a dezembro de 2016, em ato contra a PEC 241, que tinha como proposta o congelamento dos gastos públicos por vinte anos.

Fora um momento de mobilização, cuja ação não se prendeu somente ao espaço físico do prédio principal. Os estudantes participaram de manifestações no Rio de Janeiro e em Brasília, sendo este último marcado por forte repressão policial. O "Ocupa UFRRJ" aconteceu com um diferencial das demais universidades, de forma a ocupar primeiramente o prédio principal da UFRRJ (P1) e posteriormente os institutos da Universidade. Aos poucos, pois, a instituição era tomada por estudantes que traziam a discussão nacional para seus próprios contextos de debate e de reflexão. 


\section{NOTA DE APOIO DO C.A DANDARA DOS PALMARES AO} MOVIMENTO DE OCUPAÇÃO DA UFRURaIRJ

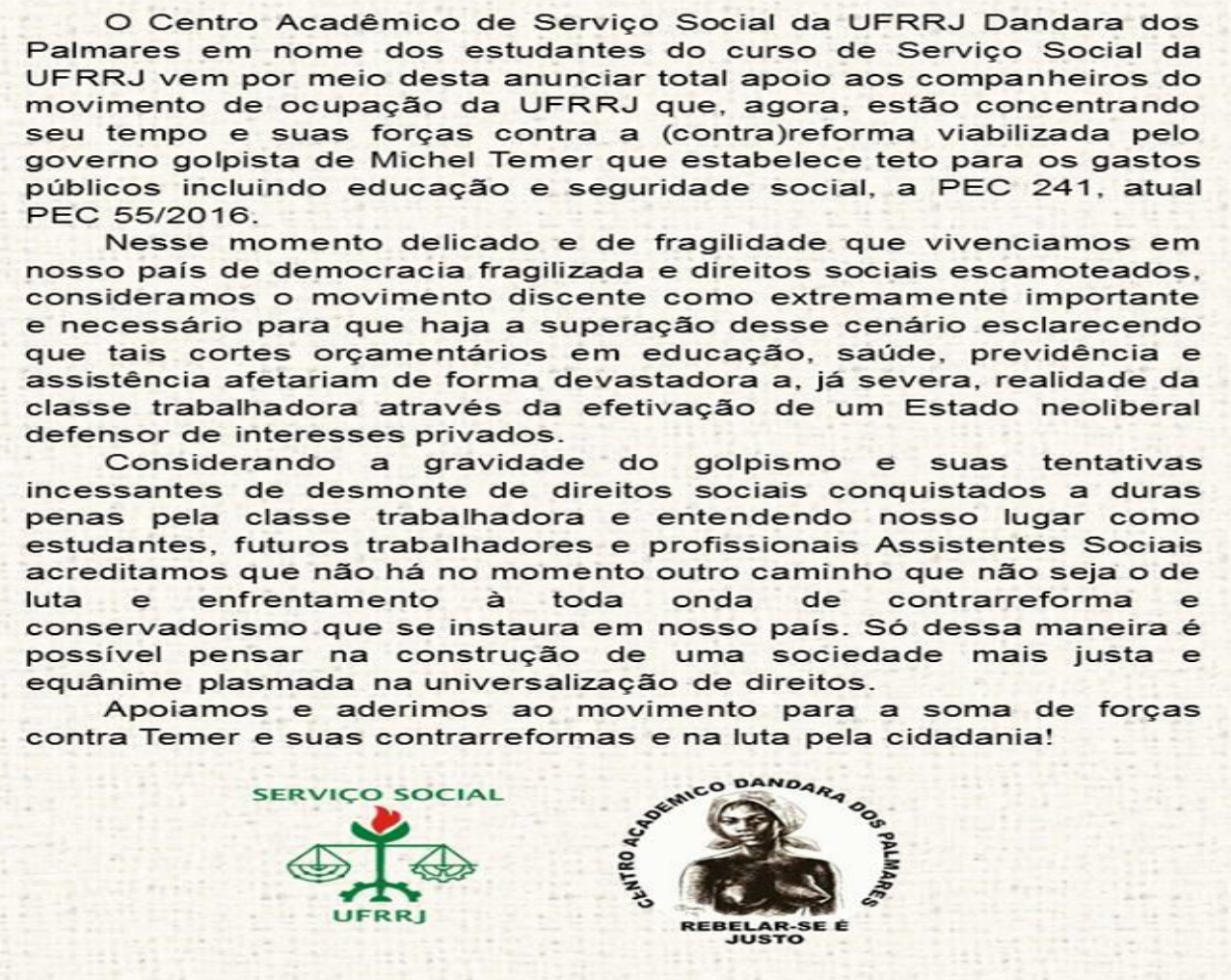

Figura 8 - Nota de repúdio emitida pelo CASS UFRRJ durante o "Ocupa UFRRJ"

Foi possível constatar, a partir de relatos dos estudantes, que entre os ocupantes se criou um relacionamento coletivo a partir das dificuldades e dos problemas enfrentados. A ocupação, apesar de somente os estudantes universitários da Rural terem-na realizado, proporcionou também uma unidade entre alunos, professores, técnicos servidores e secundaristas. Um espaço de resistência e de formação política, onde se tinha a luta pela permanência de direitos, já tão duramente violados. A memória e a identidade do Curso, assim, se projetava para alcançar outros sujeitos, sem, com isso, perder suas características próprias de serem contadas e vivenciadas pelos discentes - formação pela experiência que, no caso do Curso em questão se iniciou junto à própria Graduação, e antes do Movimento de Ocupação dos estudantes que aconteceria um ano depois, nacionalmente.

Apesar de toda luta, a inicial PEC 241, posteriormente denominada PEC 55, foi aprovada no dia 13 de dezembro de 2015. O “Ocupa UFRRJ" foi um marco para os discentes da Universidade e para os discentes de Serviço Social, marco esse que construiu de forma coletiva uma memória, a ser registrada de forma saudosa, mas não com menos luta, porque formativa, 
porque tomadora de palavras pelos próprios sujeitos coletivos. Formação: o ingresso e a saída da Universidade não pode ser, apenas, um rito de passagem. Para os movimentos sociais que chegam a este espaço, a conquista não é palavra de representação maior. A possibilidade de ocupação, via memorial que excede, este sim, pode constituir uma nova possibilidade de se (re)colocar novos diálogos neste que (ainda é) um dos espaços mais conservadores e assim mantidos por projetos societários dominantes de uma hegemonia não democrática.

\section{Considerações finais}

"A pedagogia do oprimido que, no fundo, é a pedagogia dos homens empenhando-se na luta por sua libertação" tem suas raízes na "inserção crítica das massas na sua realidade através da práxis". (FREIRE, Op.cit. 55). Na práxis autolibertadora, as massas erguem-se como portadoras de um passado espoliado e dele retiram o núcleo ainda vivo da verdade contida nas ruínas, nas perdas, nas derrotas esquecidas como algo sem sentido num tempo em que o progresso histórico aferra-se em suas forças destrutivas. A redescoberta do passado está acompanhada da produção de um tipo de prática social, constituída na dialética entre experiência e memória, que expressa o movimento das mulheres e homens agindo para interromperem o presente, fazendo das ruínas que o constituem a condição histórica para a libertação de forças socialmente reprimidas, a partir de então voltadas para a construção de um novo tempo.

É neste sentido que a pedagogia do oprimido pode representar as atuais formas de resistência produzidas na América Latina que têm na ocupação um elemento comum, ou seja, o processo em que são produzidas experiências horizontalmente compartilhadas no movimento dialético que entrelaça liberdade e autonomia, criando, assim, uma nova memória. Memória que pode ser tomada como base para novas experiências ainda mais profundas e transformadoras. É assim que a transformação do presente, a partir da rememoração do passado, restitui nas mulheres e nos homens "o tendão de sua melhor força", que, para Walter Benjamin, "se nutre da visão dos ancestrais escravizados" (BENJAMIN, 2005, p.108), qualidades essenciais de um tipo de luta que se forma capaz de subverter o curso da história.

Os anos que se seguiram a 1968 evidenciaram o processo de esgotamento da estrutura capitalista, incluindo as formas de luta tradicionais do proletariado, indicando ao mesmo tempo o potencial emancipatório das formas de resistência que encontram na Pedagogia do Oprimido uma "filosofia da práxis". Neste ensaio, a experiência de ocupação produzida pelo movimento estudantil em 2016 foi destacada no ponto em que rememora, na prática, a horizontalidade política e cultural que esteve na base das manifestações estudantis de Maio de 1968 em Paris, 
recusando tanto a dominação da estrutura capitalista quanto os modos ditatoriais de construção do socialismo, que, na prática, reatualizaram as formas abstratas de dominação do valor. (MÉSZAROS, 2002).

Ademais, a pluralidade cultural e temática das atividades de formação organizadas durante as ocupações também remonta a memória do maio francês, na sua diversidade descentralizada, que se ampliou em modos de resistência. Neste sentido, o próprio processo de auto-organização estudantil nas escolas e universidades brasileiras que inicialmente se voltaram para barrar as medidas parlamentares regressivas também produziu críticas à forma tradicional de educação, ao experienciar que a práxis emancipatória é educação popular, processo de autoformação que produz a "concidência entre a modificação das ciscunstâncias e a automodificação humana"xvi , base histórica originária da pedagogia freireana.

Nesse sentido é que, pelas experiências formativas a partir dos coletivos, temos podido vivenciar não a (re)atualização da obra de Freire, mas compreender como e porquê seus pensamentos continuam entre nós, apesar das práticas opressoras, que tentam silenciar as práxis pedagógicas, a resistência como bem pontuou o autor há tanto tempo ainda é, justamente, o nãocalar. Pela palavra sua, que se toma a cada organização, a cada movimento, essa mesma palavra assume um (novo) lugar, para o grupo e para cada sujeito.

A experiência e a memória, portanto, se tornam, na contemporaneidade, mais do que elementos de ação. Devemos entendê-las como categorias-chave, conceitos-luta, de modo a continuar resistindo a toda e qualquer forma de opressão que, no fundo, se constitui como tentativas de não-ser do outro. Por mais cinquenta anos, a Pedagogia do oprimido continuará atemporal, queremos crer, mas, quem sabe, em outro sentido: nem tanto pela resistência à negação do convite ao coletivo, como nos alerta Freire na epígrafe inicial desse diálogo, mas pelas proposições dos movimentos sociais frente a projetos societários efetivamente emancipatórios.

\section{Referências}

ARANTES, Paulo Eduardo. Extinção. Coleção Estado de Sítio. São Paulo: Boitempo, 2007. ARANTES, Paulo Eduardo; ARANTES, Otília Beatriz Fiori. Sentido da formação. São Paulo: Paz e Terra, 1997.

BUARQUE, Chico. Estorvo. São Paulo: Companhia das Letras, 1991.

CUNHA, A. G. da. Dicionário Etimológico da Língua Portuguesa. $4^{\mathrm{a}}$ ed. Rio de Janeiro: Lexikon editorial, 2010. 
GALEANO, Eduardo. As veias abertas da América Latina. 49. ed. São Paulo: Paz e Terra, 2009. HALBWACHS, Maurice. A memória coletiva. Trad. Beatriz Sidou. São Paulo: Centauro, 2013. HOBSBAWM, Eric. Era dos extremos: o breve século XX, 1914-1991. São Paulo: Companhia das Letras, 1995.

HOLANDA, S. B. Raízes do Brasil. Prefácio. 26. ed. São Paulo: Companhia das Letras, 1995. FERNANDES, Florestan. A revolução burguesa no Brasil: ensaio de interpretação sociológica. 5. ed. São Paulo: Globo, 2006.

FERNANDES, Marco. Quando o desemprego dignifica o homem e a mulher: lições piqueteras sobre a difícil arte de organizar movimentos populares nas metrópoles neoliberais. Disponível em: < http://antivalor.atspace.com > Acesso em: 20 mar. 2011.

FERREIRA, Adriana Almaral. Ensaios das formas de resistência na história: crítica do capital e práxis emancipatória. 2013. 200f. Doutorado (Tese). UFRJ. Universidade Federal do Rio de Janeiro (UFRJ), 2013.

FREIRE, Paulo. Pedagogia do oprimido. Rio de Janeiro: Paz e Terra, 2011.

SILVA, Maria Apareceida Moraes. A luta pela terra: experiência e memória. São Paulo: UNESP, 2004.

MARCUSE, Herbert. A grande recusa hoje. Petrópolis, RJ: Vozes, 1999.

MENEGAT, Marildo. Sem lenço nem aceno de adeus. Formação de massas em tempo de barbárie: como a esquerda social pode enfrentar esta questão?. Praia Vermelha, n. 18. Rio de Janeiro: PPGSS/UFRJ, 2008.

. "Unidos por catástrofes permanentes: o que há de novo nos movimentos sociais da América Latina" in: Anais... VII SIMPÓSIO NACIONAL ESTADO E PODER: SOCIEDADE CIVIL, 2012, Uberlândia, MG.

NORA, Pierre. Pierre Nora en Les lieux de mémoire. Montevideo: Trilce, 2008.

PAIVA, Vanilda. Paulo Freire e o nacionalismo desenvolvimentista. São Paulo: Graal, 2000.

POLLAK, Michel. Memória e identidade social. In: Estudos Históricos, Rio de Janeiro, vol. 5, $\mathrm{n}^{\circ} 10,1992$, p. $200-212$.

SECCO, Lincoln. História do PT 1978-2010. Cotia, SP: Ateliê Editorial, 2011.

SCHWARZ, Roberto. O fio da meada. In. Que horas são? São Paulo: Companhia das Letras, 1989. . Cultura e política. 2. ed. São Paulo: Paz e Terra, 2005. . Um romance de Chico Buarque. In. Sequências Brasileiras. São Paulo: Companhia das Letras, 1999. 


\section{i Professora adjunta do Departamento de Serviço Social da UFES}

ii Professora Adjunta da Universidade Federal Rural do Rio de Janeiro - UFRRJ. Departamento de Teoria e Planejamento de Ensino - DTPE/IE. Coordenação do Curso de Serviço Social - CCSS/ICSA

iii Cf. MARCUSE, H. Herbert Marcuse fala aos estudantes. In. MARCUSE, H. A grande recusa hoje. Petrópolis, RJ: Vozes, 1999. p. 57-70. No Brasil, esta obra de Marcuse foi traduzida e organizada por Isabel Loureiro, com o apoio de intelectuais como Carlos Nelson Coutinho, ambos estudiosos de alternativas revolucionárias pela via democrática, com base no pensamento de Rosa Luxemburgo e Antônio Gramsci.

iv "A mudança social mais impressionante e de mais longo alcance da segunda metade do século XX, e que nos isola para sempre do mundo do passado, é a morte do campesinato." "Na América Latina, a porcentagem de camponeses se reduziu à metade em vinte anos na Colômbia (1951-73), no México (1960-80) e - quase - no Brasil (1960-80). Caiu em dois terços, ou quase isso, na República Dominicana (1960-81), Venezuela (1961-81) e Jamaica (1953-81). Em todos esses países - com exceção da Venezuela -, no fim da Segunda Guerra Mundial os camponeses formavam metade, ou a maioria absoluta, da população ocupada. Mas em 1970 não havia na América Latina - fora dos miniEstados da tripa de terra centro-americana e do Haiti - um único país em que os camponeses não fossem minoria." (Cf. HOBSBAWM, E. Revolução social: 1945-90. In. HOBSBAWM, E. Era dos extremos: o breve século XX, 1914-1991. São Paulo: Companhia das Letras, 1995. p. 284-5).

${ }^{\vee}$ Em suas palavras, "Os ideais absorvidos gravitavam em torno da reprodução interna da ordem econômica das "nações avançadas', que exerciam hegemonia econômica, cultural, política e diplomática sobre o país." (Cf. FERNANDES, F. A revolução burguesa no Brasil: ensaio de interpretação sociológica. 5. ed. São Paulo: Globo, 2006, p. 105).

${ }^{\text {vi }}$ O ISEB foi criado em 1955, pelo Ministério de Educação e Cultura, destinado ao estudo, ao ensino e à divulgação das ciências sociais. Naquele contexto, os intelectuais isebianos dedicavam-se ao tema do desenvolvimentismo. Tomaremos o estudo de Vanilda Paiva, "Paulo Freire e o nacionalismo desenvolvimentista", como referência principal para tratar do pensamento freireano no período de sua emergência. (Cf. PAIVA, V. Paulo Freire e o nacionalismo desenvolvimentista. São Paulo: Graal, 2000).

vii Sobre os intelectuais brasileiros, segundo Candido, Sérgio Buarque de Holanda, em Raízes do Brasil, fala da "satisfação com o saber aparente, cujo fim está em si mesmo e por isso deixa de aplicar-se a um alvo concreto, sendo procurado sobretudo como fator de prestígio para quem sabe." A confiança nas ideias era levada ao máximo, "mesmo quando inaplicáveis", o que, na interpretação de Holanda, foi o caso do positivismo no Brasil. (Cf. CANDIDO, A. O significado de "Raízes do Brasil". In. HOLANDA, S. B. Raízes do Brasil. Prefácio. 26. ed. São Paulo: Companhia das Letras, 1995. p. 18).

viii Cf. SCHWARZ, R. Op cit. p. 20. Grifos meus

ix Thompson, em seu livro Senhores e caçadores, apresenta análises interessantes sobre o domínio de classe, elaborando compreensões de que a dominação determinada pelo consenso e pela regulação da lei "pode disfarçar as verdadeiras realidades do poder, mas ao mesmo tempo podem refrear esse poder e conter seus excessos". Na edificação dessas relações dominantes e dominadas, os valores culturais que legitimam o modo de vida burguês, sob a regulação da lei, representam uma "realização cultural autêntica" que opera como mediação das relações de classe, haja vista que a verdadeira legitimidade do domínio burguês só pode ser alcançada com a adesão dos trabalhadores. (Cf. THOMPSON, E. P. Senhores e caçadores. Rio de Janeiro: Paz e Terra. 1987. “O domínio da lei”, p. 348-361).

${ }^{x}$ Maria Aparecida de Moraes Silva, em seu A luta pela terra: experiência e memória, apresenta análises importantes para a compreensão da história recente da estrutura agrária no Brasil, que foi moldada pelo processo modernizador acelerado nos finais da década de 1950, durante o governo de Juscelino Kubitschek, e consolidado no período ditatorial. O resultado da modernização das relações e das práticas sociais no campo, que combinou assassinatos, destruição material e cultural e negação de direitos de cidadania aos trabalhadores, foram "milhares de pessoas desenraizadas social e culturalmente, perambulando de um lugar para o outro em busca de sobrevivência, sem eira nem beira, já que foram obrigados a deixar para trás tudo o que possuíam. Transformaram-se em verdadeiros errantes. Um dos pontos de parada foi a periferia das cidades. [...] As pessoas não foram para a cidade atraídas por suas luzes; elas foram forçadas a deixar seu lugar, entendido não somente como espaço físico mas como espaço cultural, como um lugar onde foi possível criar um modo de vida caracterizado pela sociabilidade baseada nas relações com parentes e vizinhos e na religiosidade, capaz de unir a natureza, a terra, as pessoas e os santos padroeiros.” (Cf. SILVA, M. A. M. A luta pela terra: experiência e memória. São Paulo: UNESP, 2004. p. 40).

xi O filme de Eduardo Coutinho, "Cabra marcado para morrer", é uma interessante produção sobre as lutas camponesas, sobretudo porque foi um projeto que teve início antes de 1964, mas que só pôde ser concluído em 1981, dadas as circunstâncias políticas do país. Roberto Schwarz, em seu "O fio da meada" faz uma análise relevante e instrutiva do filme que retrata, a partir da memória daqueles que viveram os anos que antecederam o golpe de 1964, a prática política dos camponeses no nordeste, observada pelos estudantes que viajaram o país na "UNE Volante", um projeto que representava uma aliança, impossível nos dias de hoje, entre o governo nacional e 
as reivindicações populares. No entanto, o crítico capta do filme a mudança fundamental que se passou com os sujeitos históricos daquele distante episódio da vida política brasileira: "Dezessete anos depois, em 1981, o cineasta vai ao Norte em busca de seus companheiros e personagens. Leva o filme antigo e uma câmera. Atrás dele agora não há movimento estudantil ou facilidades governamentais, nem existe entusiasmo nacional. Em lugar da efervescência social e de suas formas de invenção muito socializadas, está um indivíduo mais ou menos sozinho, movido por sua fidelidade a pessoas e a um projeto, só contando com poucos recursos. É evidente outro sujeito. [...] Nem os camponeses, enfim, são os mesmos. [...] O reencontro é caloroso, mas o momento é outro. [...]" (Cf. SCHWARZ, R. O fio da meada. In. Que horas são? São Paulo: Companhia das Letras, 1989.).

xii Conforme Lincoln Secco, em seu livro História do PT, os seis principais grupos que formavam o PT no período em que o regime civil-militar dava sinais de esgotamento eram: "o Novo Sindicalismo, forjado nas greves do $\mathrm{ABC}$; os movimentos sociais organizados junto à Igreja Católica; políticos já estabelecidos no MDB que viriam a aderir à legenda; intelectuais de esquerda; organizações trotskistas diversas; e, por fim, militantes oriundos da luta armada contra a ditadura”. (Cf. SECCO, L. História do PT 1978-2010. Cotia, SP: Ateliê Editorial, 2011; Cf. Jornal Brasil de Fato, de 15 a 21 de setembro de 2011. p. 8).

xiii $\mathrm{O}$ jornalista José Arbex reuniu importantes indicadores sociais sobre a crise no Brasil, em artigo intitulado " $O$ Brasil faz parte do mundo", publicado na revista Caros Amigos, de novembro de 2011. Entre os indicadores, está o dado de que "entre 1995 e 2010 (FHC e Lula) os gastos com a dívida externa somaram mais de R\$6,8 trilhões (dois PIBs)". Outro indicador significativo é que, durante os dez anos de governo Lula/Dilma, a média percentual da arrecadação tributária direcionada ao pagamento de juros da dívida é de 47\%. Cf. Jornal Brasil de Fato, de 10 a 16 de janeiro de 2013.

${ }^{\text {xiv }}$ Esse tema foi desenvolvido na tese de doutorado "Ensaios das formas de resistência na história: crítica do capital e práxis emancipatória", finalizada em junho de 2013, orientada pelo prof. Marildo Menegat. Cf. FERREIRA, A. Ensaios das formas de resistência na história: crítica do capital e práxis emancipatória. Programa de Pós-graduação em Serviço Social, ESS, UFRJ, 2013. p. 154-191.

${ }^{\mathrm{xv}}$ Referimo-nos, aqui, não apenas às Diretrizes Curriculares de 1996, mas, também às demais resoluções e pareceres que atualizam e complementam a indicação dessa formação. Mais informações em http://www.cfess.org.br/visualizar/menu/local/diretrizes-curriculares. Acesso em maio de 2018.

${ }^{\text {xvi }}$ Definição de Práxis em Marx, elaborada na sua $3^{\text {a }}$ tese sobre Feuerbach, em 1845. 